\title{
THE EFFECT OF COUNTRY OF ORIGIN AND PRODUCT QUALITY ON PURCHASE INTENTION: CASE OF HUAWEI SMARTPHONES
}

\author{
Hendri Budiyanto ${ }^{1}$, Arjuna Wiwaha ${ }^{2 *}$ \\ Management Program, STIE Jakarta International College, Indonesia. \\ *Corresponding Author: arjuna.wiwaha@jic.ac.id
}

\begin{tabular}{l} 
ARTICLE INFO \\
\hline Article History: \\
Received: November 10, 2020 \\
Revised: January 14, 2021 \\
Published Online: February 19, 2021
\end{tabular}

\section{Keywords:}

Country of Origin, Product Quality, Purchase Intention, Brand, Huawei Smartphone.

\author{
How to cite: \\ Budiyanto, H., Wiwaha, A. (2021). \\ The Effect of Country of Origin and \\ Product Quality on Purchase \\ Intention: Case of Huawei \\ Smartphones. International Journal of \\ Digital Entrepreneurship and \\ Business (IDEB), 2 (1), 1 - 10.
}

\begin{abstract}
This study aimed to discuss and determine the influence of Country of Origin and Product Quality on Purchase Intention for Huawei Smartphones. The research was conducted in a smartphone retail company at PT. Erafone Artha Retailindo, a branch of Roxy Mas. The research method used is library research by literature studies, scientific journals, and reports. Field research was done by collecting data from research objects through observation, interviews, and questionnaires. The data was collected from 140 visitors, who had not purchased at the Erafone branch in Roxy Mas. The valid sample used in this study amounted to 100 people. To process and analyze the data, this research used SPSS version 25. Based on the results, Country of Origin and Product Quality have a positive and significant effect either partially or simultaneously by $64.4 \%$, on Huawei Smartphone Purchase Intention; the remaining $35.6 \%$ is influenced by other factors not covered in this study.
\end{abstract}

\section{INTRODUCTION}

In the current globalization era, the geographical boundaries of a country no longer pose an obstacle between individuals in communication and interaction with other countries. Most recently, there has been a rapid worldwide development in the fields of transportation, communication, and technology. It is more obvious when telephones are compared to smartphones that use advanced technology to enhance communication between individuals around the world. This virtual communication enables seamless interaction with other individuals via short messages and telephone, although the more recent innovation is the use of internet networks.

Indonesia possesses the capability as a production base to develop world-class telecommunication equipment industries. This is supported by the large domestic market potentials and several competitive local component producers. Data from the Ministry of Industry shows that there are 24 manufacturing industries for cellphone components and tablet products in the country. According to the e-Marketer report, active Smartphone users in Indonesia have grown from 55 million people in 2015 to 100 million in 2019. Therefore, Indonesia has become the fourth largest active smartphone user in the world after China, India, and America. The Minister of Industry, Airlangga Hartarto, stated that the government is determined to promote the sustainability of the telematics industry in the country. An example is through the issuance of Minister of Industry Regulation Number 29 of 2017, on provisions and procedures for calculating the value of domestic component level (TKDN) for cellphone, handheld computer, and tablet computer products (Novalius, 2018). 


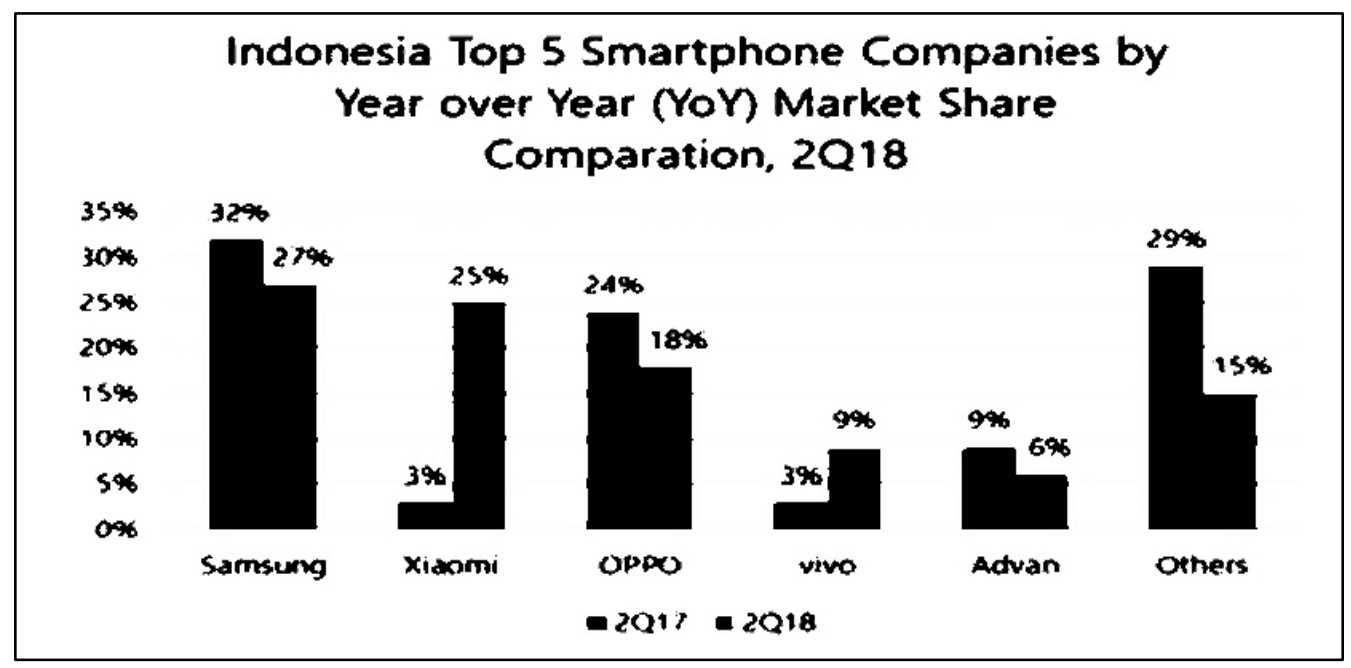

Figure 1: Smartphone sales in Indonesia (IDC, 2018).

The figure above shows a fairly high increase in Smartphone users in Indonesia. This signifies that Indonesia has a high potential market share. Furthermore, the total population according to the official annual projection as of July 1, 2019, is approximately 268 million, or $3.53 \%$ of the world's population. In the third quarter of 2018, the list of 5 Smartphones with the highest sales and market share in the world is shown in table 1 below.

Table 1: Global Smartphone Sales Report (IDC, 2018).

\begin{tabular}{|l|c|c|c|c|c|}
\hline \multirow{2}{*}{ Company } & \multicolumn{2}{|c|}{$\mathbf{3 Q 2 0 1 8}$} & \multicolumn{2}{c|}{ 3Q2017 } & \multirow{2}{*}{$\begin{array}{c}\text { Q18 / 3Q17 } \\
\text { Change }\end{array}$} \\
\cline { 2 - 5 } & $\begin{array}{c}\text { Shipment } \\
\text { Volume }\end{array}$ & $\begin{array}{c}\text { Market } \\
\text { Share }\end{array}$ & $\begin{array}{c}\text { Shipment } \\
\text { Volume }\end{array}$ & $\begin{array}{c}\text { Market } \\
\text { Share }\end{array}$ & \\
\hline Samsung & 72.2 & $20.3 \%$ & 83.3 & $22.1 \%$ & $-13.4 \%$ \\
\hline Huawei & 52.0 & $14.6 \%$ & 39.1 & $10.4 \%$ & $32.9 \%$ \\
\hline Apple & 46.9 & $13.2 \%$ & 46.7 & $12.4 \%$ & $0.5 \%$ \\
\hline Xiaomi & 34.3 & $9.7 \%$ & 28.3 & $7.5 \%$ & $21.2 \%$ \\
\hline Oppo & 29.9 & $8.4 \%$ & 30.6 & $8.1 \%$ & $-2.1 \%$ \\
\hline Others & 119.9 & $33.8 \%$ & 149.8 & $39.6 \%$ & $-19.9 \%$ \\
\hline TOTAL & $\mathbf{3 5 5 . 2}$ & $\mathbf{1 0 0 \%}$ & $\mathbf{3 7 7 . 8}$ & $\mathbf{1 0 0 \%}$ & $\mathbf{- 6 . 0 \%}$ \\
\hline
\end{tabular}

Source: IDC, 2018

The International Data Corporation (IDC) research institute released data on the top five smartphone sales in Indonesia (Figure 1). Meanwhile, table 1 above shows the five best-selling smartphones worldwide, and Huawei is in second place after Samsung. However, it is not surprising that sales in Indonesia are not good enough, as Huawei is not only a new product in the Indonesian market but the public is also confused about the product's origin. Many consumers do not understand and have different speculations about the origin of Huawei. Some believe the product is from Korea, Taiwan, or China, while others believe Huawei is from Japan. There is a negative stigma from Indonesian people regarding Smartphone products from China.

Product quality determines the customer perceptions of a company's performance, which in turn will affect customer satisfaction. The focus of customer attention is on the function, quality, benefit, and brand image of a product (Ismanto \& Susanti, 2019). Continuously increasing customer's needs tend to increase the demanded services. This becomes the rationale for fulfilling the needs, wants, and expectations of consumers for various changes.

Lin and Kao (2004) stated that the Country of Origin creates a perception of a product's brand, which is either positive or negative. The higher level of positive perceptions enables the creation of real purchases. Increasing economic globalization will lead to lower trade barriers between countries, 
therefore, the supply of foreign products in the local market has increased. Country of Origin acts as the main factor among several products' potential competition in the domestic market for each country.

Purchase intention arises when individuals obtain sufficient information on their desired product. Schiffman and Kanuk (2010) stated that a rise in consumer purchase intention is influenced by external factors such as the need for products, product introduction, and evaluation information. In this research, the intended purchase intention is that of Huawei Smartphones as one of the electronic products made in China.

The potential purchase intention of Indonesian people for Huawei is still lacking. This is obvious from the sales of Huawei smartphones, which were not included in the top five market share in Indonesia at the end of 2018 (refer to figure 1). Meanwhile, their sales in the Global market successfully attained second place, replacing Apple which fell to the third position.

Indrayani and Nurcaya (2014) concluded that Perceptions of Quality have a significant positive effect on Purchase Intention for Samsung Galaxy mobile phones in Denpasar city. Therefore, the researchers were interested in discussing these conclusions by examining one of the new smartphones in Indonesia, namely Huawei.

From the description above, the problem discussed in this research is whether there is an effect of Country of Origin and Product Quality on Purchase Intention for Huawei Smartphones at the Erafone Roxy Mas branch. Meanwhile, the aim of this study is to determine the effect of Country of Origin and Product Quality on Purchase Intention for Huawei Smartphones at the Erafone Roxy Mas branch.

\section{LITERATURE REVIEW \\ Country of Origin}

Country of Origin is the country that manufactures a product. The image of a country can differentiate a product from competing products, and significantly influences a consumer's purchasing decision. According to Purwitasari et al. (2018), the country of origin will affect people's perceptions of the product quality. The identification of the country of origin is a cue in product attributes that influences consumer evaluation. The more information the consumer has, the less the Country of Origin effect will be. Furthermore, Kotler et al. (2009) stated that mental associations and beliefs driven by a country are called the country of origin. Putra et al. (2016) state that the mental image of a country towards a product brand is called the country of origin.

According to Kotler et al. (2009), the country of origin can be stereotyped based on its industrialization. Such a stereotype is more about the perception of the quality of products manufactured in the country. Demirbag et al. (2006) stated that there are three levels of the country of origin characteristics from a marketing perspective. These include the image of the whole country, the product country, and the image of the country of origin observed in certain product categories. Furthermore, Yasin et al. (2007) stated that measurement of the country of origin effect was performed based on indicators of trust in the country, trust in individuals in the country concerned, and the desire to have a relationship with that country. According to Kotler et al. (2009), country of origin indicators is the level of technological progress, the product type of the country of origin, as well as the product prestige and quality.

\section{Product Quality}

Kotler et al. (2009) categorically stated that quality is the best guarantee for consumer loyalty, and is the strongest defense to face international competition in maintaining growth and income. Furthermore, Tjiptono (2016) stated that quality is a mixture of traits and characteristics which determine the extent to which output fulfills the requirements of consumer needs. Kotler and Armstrong (2015) also stated that product quality is the product's ability to demonstrate its function, including its durability, accuracy, reliability, ease in operation as well as repair of products and attributes. 
According to Kotler et al. (2009), customer perceptions of product quality include increased information results, competition in product categories, and changing expectations. In evaluating product quality, customers do not only consider functional aspects but also objective aspects, and subjective aspects. Finally, product quality becomes one of the basic considerations for consumers in making decisions either to buy products or not. Tjiptono (2016) stated that quality describes all dimensions of product offerings to generate benefits for consumers. The determination of a quality product can be carried out through the following dimensions:

a) Performance is the basic operating characteristic of a product.

b) Durability involves how long the product lasts for use.

c) Compliance with specifications is the extent to which the main characteristics of a product fulfill certain customer specifications.

d) Features are the characteristics designed to enhance product functionality, to increase customer's interest.

e) Reliability is the possibility that the product will work well for a specified period.

f) Service capabilities are in the form of speed, comfort, competence, ease of maintenance, and handling of customer complaints.

g) Aesthetics is the attractiveness or beauty value of a product when observed using the five senses.

h) Perceived quality is the reputation and image of the product, and the responsibility of the company.

\section{Purchase Intention}

Purchase intention is the inner motive that promotes individuals to have spontaneous and natural attention without pressure and being selective about a product which they decides to buy it. Ismanto and Susanti (2019), stated that purchase intention is the desire to own a product. This desire arises when a consumer has been affected by the quality and information on that product. Meanwhile, Dinata et al. (2015), stated that intention is one psychological aspect of a person and has a significant effect on behavioral attitudes.

Kotler et al. (2009) stated that two factors form a customer purchase intention, namely (a) other people's attitudes, specifically the urge of consumers to follow other people's desires, and; (b) unanticipated situations, or factors that change the consumer's position to buy. This depends on the mindset of consumers and confidence in making product purchases. Silaen (2018) mentioned that purchase intention can be measured through the following indicators:

a) The transactional intention is an individual's tendency to buy a product.

b) Preferential intention describes the behavior of individuals with a major preference for a product.

c) Explorative intention involves the behavior of individuals that look out for product information that they like and additional information on product advantages.

\section{Hypothesis Development:}

\section{Country of Origin on Purchase Intention}

Silaen (2018) concluded that the Country of Origin affects Purchase Intention. Most of the customers are interested in the product. They believe that products come from a developed country that has been proven in terms of technology. Therefore, more the development of a country, more would be the customers' Purchase Intention.

H1: There is a positive and significant effect of Country of Origin on Purchase Intention for Huawei Smartphones.

\section{Product Quality on Purchase Intention}

Wicaksono (2016) concluded that Product Quality has a positive and significant effect on Purchase Intention. Consumers consider product quality with price. Purchase intention arises from the desire of consumers to see product quality, therefore they do not quickly change products. This signifies that product quality can increase customers' Purchase Intention.

$\mathrm{H}_{2}$ : There is a positive and significant effect of product quality on the Purchase Intention for Huawei Smartphones. 


\section{Country of Origin and Product Quality on Purchase Intention}

Consumers are interested in which country (country of origin) the product is produced. Therefore, it is believed that an advanced country of origin with high technology can create good quality products.

H3: There is a positive and significant effect between Country of Origin and Product Quality on Purchase Intention for Huawei Smartphones.

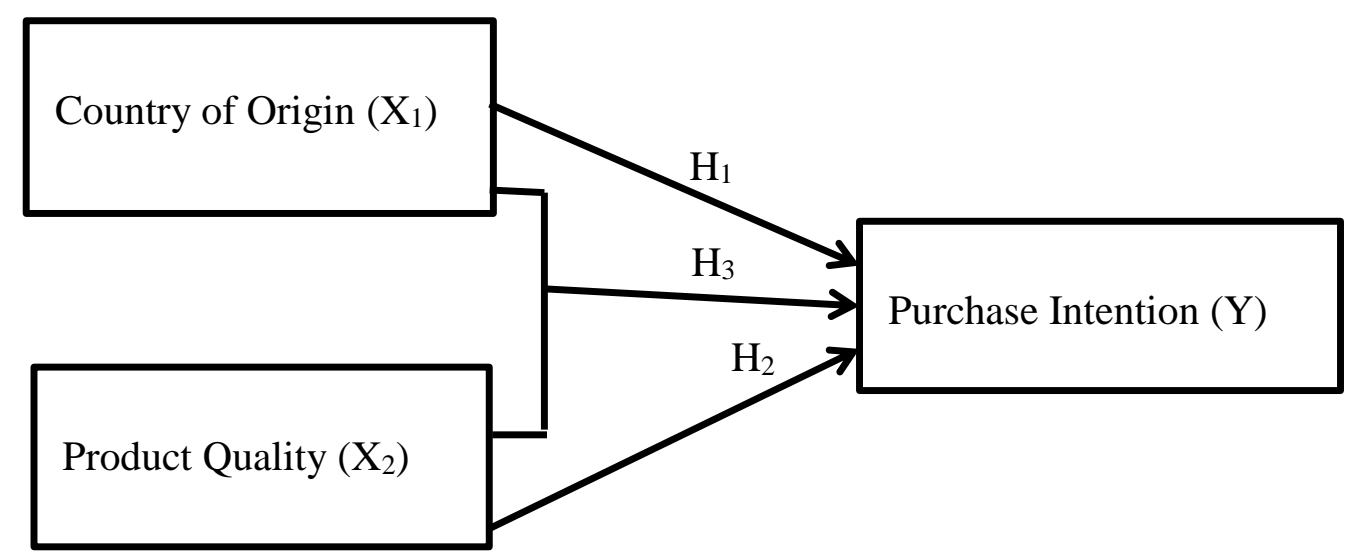

Figure 2: Research Model

\section{METHOD}

This research was conducted at a smartphone retail company PT. Erafone Artha Retailindo, at Roxy Mas branch, in Central Jakarta from September till December 2019. The research method involved literature and field research. According to Riadi (2016), a population is a place of an object/subject studied, in form of objects, people, events, values, or other things that have certain quantities and characteristics to obtain information.

In this research, the data was collected from all visitors or potential customers of the Erafone Roxy Mas branch amounting to 140 people, who have not made a purchase transaction. The valid and complete sample in this research was 100 respondents, with an error rate of $\alpha$ of 5\% (Sugiyono, 2016).

A Questionnaire is a highly flexible, easy-to-use data collection instrument. The data it obtains is categorized as factual data. The questions contained in it help to determine the answers of respondents about the variable Country of Origin, Product Quality, and Purchase Intention. A questionnaire is said to be valid if the question in it describes something that will be measured by the questionnaire (Ghozali, 2016).

The validity test in this research was performed by distributing 30 questionnaires for empirical testing in the field (Sugiyono, 2014). From the product-moment correlation test with 30 respondents, the $r_{\text {table }}$ value is 0.361 . All indicators of the instruments used in this research exceeded the $r_{\text {table }}$ of 0.361 . Therefore, all research instruments were concluded valid.

Reliability is a tool used to measure a questionnaire which is an indicator of a variable. The questionnaire is said to be reliable when the answers from respondents to statements are consistent over time (Ghozali, 2016). The reliability test uses the Cronbach's alpha statistical test, where the variable studied had a Cronbach's alpha value above 0.6 (Widjoyo, 2013). The reliability test results of the three variables above are shown in Table 2 below. 
Table 2: Reliability Statistic

\begin{tabular}{|l|c|c|}
\hline Reliability Statistic & Cronbach's Alpha & No of Items \\
\hline Country of Origin $\left(\mathrm{X}_{1}\right)$ & 0.929 & 10 \\
\hline Product Quality $\left(\mathrm{X}_{2}\right)$ & 0.890 & 9 \\
\hline Purchase Intention $(\mathrm{Y})$ & 0.899 & 7 \\
\hline
\end{tabular}

Source: Primary Data, SPSS 25, 2020

From table 2, the Cronbach's alpha value for the three variables is greater than 0.6. Therefore, it was concluded that the instrument used is reliable.

\section{RESULT AND DISCUSSION}

Data collection in this research involved the distribution of questionnaires to visitors of the Erafone outlet, Roxy Mas branch. The information obtained from 100 respondents were as follows:

Table 3: Respondent Profile

\begin{tabular}{|c|c|c|}
\hline No. & Type of Information & Description \\
\hline 1. & Gender & $\begin{array}{l}\text { Male }=41 \text { people, } \\
\text { Female }=59 \text { people }\end{array}$ \\
\hline 2. & Education & $\begin{array}{l}\text { Elementary School }=3 \text { respondents, } \\
\text { Junior High School }=23 \text { respondents, } \\
\text { Senior High School }=45 \text { respondents, } \\
\text { Diploma } 3=13 \text { respondents, } \\
\text { Undergraduate Program }=12 \text { respondents, } \\
\text { Graduate Program }=4 \text { respondents }\end{array}$ \\
\hline 3. & Age & $\begin{array}{l}<18 \text { years }=1 \text { respondents, } \\
18-25 \text { years }=42 \text { respondents, } \\
26-35 \text { years }=31 \text { respondents, } \\
36-45 \text { years }=10 \text { respondents, } \\
>45 \text { years }=16 \text { respondents }\end{array}$ \\
\hline 4. & Occupation & $\begin{array}{l}\text { Private employee }=61 \text { respondents, } \\
\text { Housewife }=13 \text { respondents, } \\
\text { Laborer }=10 \text { respondents, } \\
\text { Civil servant }=8 \text { respondents, } \\
\text { Entrepreneur }=8 \text { respondents. }\end{array}$ \\
\hline
\end{tabular}

Source: Primary Data, 2020

The coefficient of determination analysis was used to determine and measure the model's ability to explain the various dependent variables. From the test, the coefficient of determination was obtained, as:

Table 4: Determination Coefficient Test of Country of Origin $\left(\mathrm{X}_{1}\right)$ on Purchase Intention $(\mathrm{Y})$

\begin{tabular}{|c|c|c|c|c|}
\hline \multicolumn{5}{|c|}{ MODEL SUMMARY } \\
\hline Model & R & R-Square & Adjusted R Square & Std. Error of the Estimate \\
\hline 1 & $.777^{\mathrm{a}}$ & .604 & .600 & 2.50998 \\
\hline \multicolumn{5}{|c}{ a. Predictors: (Constant), COUNTRY OF ORIGIN } \\
\hline
\end{tabular}

Source: Primary Data, 2020 
The Effect of Country of Origin and Product Quality on Purchase Intention: Case of Huawei Smartphones

From Table 4, the coefficient of determination $=\mathrm{R}^{2} \times 100 \%$ is $0.604 \times 100=60.4 \%$. This shows that $60.4 \%$ of Purchase Intention for Huawei Smartphones in the Erafone Roxy Mas branch is influenced by the Country of Origin.

Table 5: Determination Coefficient Test of Product Quality $\left(\mathrm{X}_{2}\right)$ on Purchase Intention (Y)

\begin{tabular}{|c|c|c|c|c|}
\hline \multicolumn{5}{|c|}{ MODEL SUMMARY } \\
\hline Model & R & R-Square & Adjusted R Square & Std. Error of the Estimate \\
\hline 1 & $.757^{\mathrm{a}}$ & .572 & .568 & 2.60951 \\
\hline \multicolumn{5}{|c|}{ a. Predictors: (Constant), PRODUCT $Q U A L I T Y$} \\
\hline
\end{tabular}

Source: Primary Data, 2020

From Table 5, the coefficient of determination $=\mathrm{R}^{2} \times 100 \%$ is $0.572 \times 100=57.2 \%$. Therefore, $57.2 \%$ of Purchase Intention for Huawei Smartphones in the Erafone Roxy Mas branch is influenced by Product Quality.

Table 6: Determination Coefficient Test of Country of Origin $\left(\mathrm{X}_{1}\right)$ and Product Quality $\left(\mathrm{X}_{2}\right)$ Determination on Purchase Intention (Y).

\begin{tabular}{|c|c|c|c|c|}
\hline \multicolumn{5}{|c|}{ MODEL SUMMARY } \\
\hline Model & R & R-Square & Adjusted R Square & Std. Error of the Estimate \\
\hline 1 & $.802^{\mathrm{a}}$ & .644 & .636 & 2.39382 \\
\hline \multicolumn{5}{|c|}{ a. Predictors: (Constant), Product Quality, Country of origin } \\
\hline
\end{tabular}

Source: Primary Data, 2020

From Table 6, the coefficient of determination $=\mathrm{R}^{2} \times 100 \%$ is $0.644 \times 100 \%=64.4 \%$. This shows that 64.4\% of Purchase Intention for Huawei Smartphones in the Erafone Roxy Mas branch is influenced by the Country of Origin and Product Quality. Meanwhile, the remaining 35.6\% is estimated to be influenced by other factors.

\section{Hypothesis Testing}

\section{T-Test}

T statistical test is used to test the significance level of the relationship between independent and dependent variables.

Table 7: T Statistical Test of Country of Origin and Product Quality on Purchase Intention

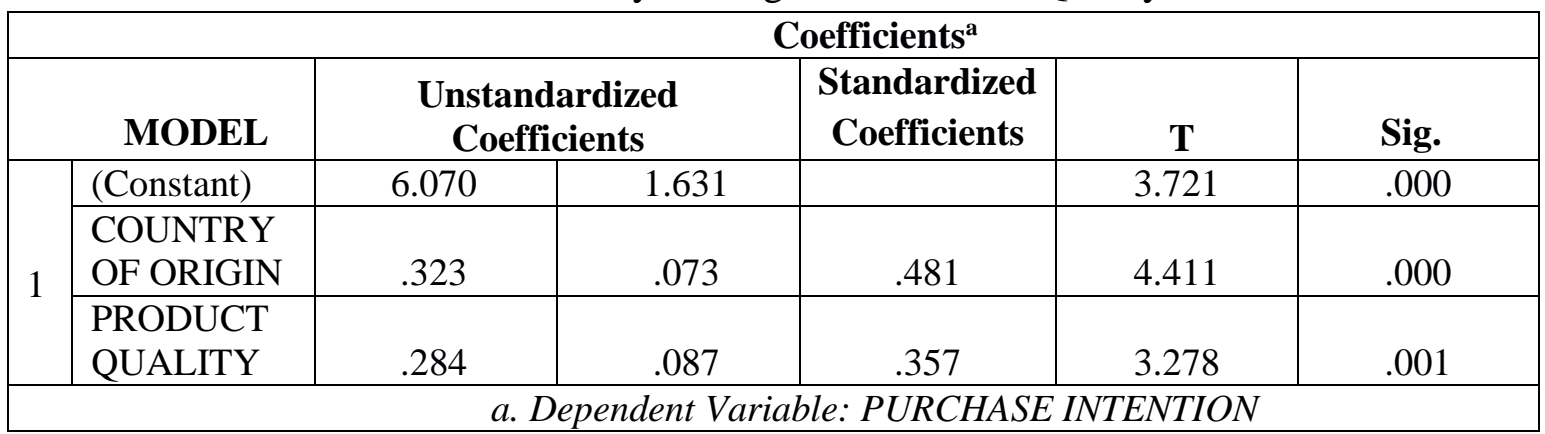

Source: Primary Data, 2020

The output results in table 7 above, used the SPSS version 25 data processing and compared the $t_{\text {count }}$ with the $t_{\text {table. }}$ 


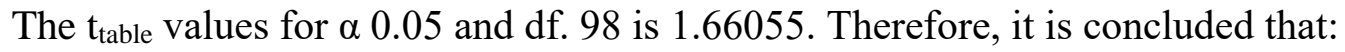

a) Country of Origin has a significant value of $0.000<0.05$ and $t_{\text {count }}=4.411>t_{\text {table }}=1.66055$. This signifies that the Country of Origin $\left(\mathrm{X}_{1}\right)$ has a positive effect on Purchase Intention $(\mathrm{Y})$.

b) Product quality has a significant value of $0.001<0.05$ and $t_{\text {count }} 3.278>t_{\text {table }} 1.66055$. This signifies that the Product Quality $\left(\mathrm{X}_{2}\right)$ has a positive effect on Purchase Intention (Y).

According to (Ghozali, 2016) decision making can be carried out using a significant probability number:

a) If the significance probability value $<0.05$ or the value of $t_{\text {count }}>t_{\text {table }}$, there is an effect of variable $\mathrm{X}$ on $\mathrm{Y}$.

b) If the significance probability value $>0.05$ or the value of $t_{\text {count }}<t_{\text {table, }}$, there is no effect of variable $\mathrm{X}$ on $\mathrm{Y}$.

From the test results, it is concluded that the value of $t_{\text {count }}=4.411>t_{\text {table }}=1.66055$, which means that $\mathrm{H}_{0}$ is rejected and $\mathrm{H}_{\mathrm{a}}$ is accepted. Therefore, there is a significant positive effect of Country of Origin on Purchase Intention for Huawei Smartphones at the Erafone Roxy Mas branch.

The test results above also show that the value of $\mathrm{t}_{\text {count }}=3.278>\mathrm{t}_{\text {table }}=1.66055$, which means that $\mathrm{H}_{0}$ is rejected and $\mathrm{H}_{\mathrm{a}}$ is accepted. Therefore, there is a positive and significant effect of Product Quality on Purchase Intention for Huawei Smartphones at the Erafone Roxy Mas branch.

\section{F Test}

The $\mathrm{F}$ test was performed to test the significance of all observed regression lines, whether $\mathrm{Y}$ has a linear relationship with $\mathrm{X}_{1}$ and $\mathrm{X}_{2}$. The $\mathrm{F}$ statistical test value is as follows:

Table 8: F Statistical Test of Country of Origin $\left(\mathrm{X}_{1}\right)$ and Product Quality $\left(\mathrm{X}_{2}\right)$ on Purchasing Intention (Y)

\begin{tabular}{|c|l|c|c|c|c|c|}
\hline \multicolumn{7}{|c|}{ ANOVA $^{\mathbf{a}}$} \\
\hline \multicolumn{2}{|c|}{ Model } & Sum of Sq. & Df & Mean Square & F & Sig. \\
\hline \multirow{2}{*}{1} & Regression & 1004.665 & 2 & 502.333 & 87.662 & $.000^{\text {b }}$ \\
\cline { 2 - 7 } & Residual & 555.845 & 97 & 5.730 & & \\
\cline { 2 - 7 } & Total & 1560.510 & 99 & 502.333 & & \\
\hline \multicolumn{7}{|c|}{ bependent Variable: PURCHASE INTENTION } \\
\hline \multicolumn{6}{|c|}{ ORIGIN Predictors: (Constant), PRODUCT QUALITY, COUNTRY OF } \\
\hline
\end{tabular}

Source: Primary Data, 2020

Table 8 above shows that the ANOVA test had the value of $F_{\text {count }}=87.662$ with a significance value of 0.000. The following decisions can be made based on this model:

a) If the sig value $<0.005\left(\mathrm{~F}_{\text {count }}>\mathrm{F}_{\text {table }}\right)$, there is a simultaneous effect of $\mathrm{X}$ on $\mathrm{Y}$.

b) If the sig value $>0.005\left(\mathrm{~F}_{\text {count }}<\mathrm{F}_{\text {table }}\right)$, there is no simultaneous effect of $\mathrm{X}$ on $\mathrm{Y}$.

Partially, Country of Origin $\left(\mathrm{X}_{1}\right)$ has a significant positive effect on Purchase Intention (Y) for Huawei Smartphones at the Erafone Roxy Mas branch. The T-test statistical results for the Country of Origin variable showed $t_{\text {count }} 4.411>t_{\text {table }} 1.66055$ with a significance level of 0.05 . Therefore, the hypothesis which stated that Country of Origin $\left(\mathrm{X}_{1}\right)$ has an effect on Purchase Intention (Y) for Huawei Smartphones at the Erafone Roxy Mas branch is accepted at a significance level of 5\%. It is also 
concluded that the Country of Origin $\left(\mathrm{X}_{1}\right)$ has a positive and significant effect on Purchase Intention (Y).

Partially, Product Quality $\left(\mathrm{X}_{2}\right)$ has a positive and significant effect on Purchase Intention (Y) for Huawei Smartphones at the Erafone Roxy Mas branch. The results of the $\mathrm{T}$ statistical test for the Product Quality variable $\left(\mathrm{X}_{2}\right)$ showed that $\mathrm{t}_{\text {count }} 3.278>\mathrm{t}_{\text {table }} 1.66055$ with a significant level of 0.05 . Therefore, the hypothesis which stated that Product Quality $\left(\mathrm{X}_{2}\right)$ has an effect on purchase intention (Y) for Huawei Smartphone at Erafone Roxy Mas branch is accepted with an error rate of 5\%. It is also concluded that Product Quality $\left(\mathrm{X}_{2}\right)$ has a positive effect on Purchase Intention (Y).

The Country of Origin $\left(\mathrm{X}_{1}\right)$ and Product Quality $\left(\mathrm{X}_{2}\right)$ have a simultaneous positive effect on Purchase Intention (Y) for Huawei Smartphones. This is evident by a significance value smaller than 0.005. Therefore, the results of the $F$ test were then consulted with the value of $F_{\text {table }}$ with Df numerator (independent variable $)=2$ and Df denominator $(n-k-1=100-2-1=97)$ at an error rate of $5 \%=0.005$. From these results, the value of $F_{\text {count }} 87.662>F_{\text {table }} 3.09$, and a value of $0.000<0.005$, which means that $\mathrm{H}_{0}$ is rejected and $\mathrm{H}_{\mathrm{a}}$ is accepted. Furthermore, the correlation is significant and also shows that the Country of Origin and Product Quality simultaneously affect the Purchase Intention for Huawei Smartphones at the Erafone Roxy Mas branch.

\section{CONCLUSION}

It can be concluded that based on the findings that $60.4 \%$ of Purchase Intention for Huawei Smartphones at the Erafone Roxy Mas branch is influenced by the Country of Origin. 57.2\% of Purchase Intention for Huawei Smartphones at the Erafone Roxy Mas branch is influenced by the Product Quality. 64.4\% of Purchase Intention for Huawei Smartphones at the Erafone Roxy Mas branch is simultaneously influenced by the Country of Origin and Product Quality, while the remaining 35.6\% is influenced by other factors. All of the above hypotheses are accepted. However, this research was limited to the variables studied, namely Country of Origin, Product Quality, and Huawei Purchase Intention. Future research can be carried out with some additional variables, to observe impact on Huawei smartphone's Purchase Intention.

\section{REFERENCES}

Demirbag, M., Tatoglu, E., Tekinkus, M., \& Zaim, S., (2006). An Analysis of The Relationship Between TQM Implementation and Organizational Performance: Evidence from Turkish SMEs. Journal of Manufacturing Technology Management, Vol. 17, No. 6, 829-847.

Dinata, J.S., Kumaji, S., \& Hidayat, K., (2015). Country of Origin dan Pengaruhnya Terhadap Persepsi Kualitas dan Minat Beli iPad di Indonesia. Jurnal Administrasi Bisnis (JAB), Vol. 25, No. 1: 1-8.

Ghozali, I. (2016). Aplikasi Analisis Multivariate dengan Program IBM SPSS 25, Badan Penerbit Unibersitas Diponegoro, Semarang.

Indrayani, L. \& Nurcaya, I.N. (2014). Peran Persepsi Kualitas Produk Dalam Memediasi Pengaruh Gaya Hidup Terhadap Niat Beli Handphone Samsung Galaxy di Kota Denpasar. E Jurnal Manajemen, 3(4), 884-901.

Ismanto \& Susanti, E. (2019). Pengaruh Citra Merek dan Kualitas Pelayanan terhadap Minat Beli pada Toko Prima Fresh Mart, Jurnal Ilmiah Widya Ekonomika, Vol. 2(1), 46-54.

Kotler, P. \& Armstrong, G. (2015). Prinsip-Prinsip Pemasaran, Jilid 2, Edisi Kedelapan, Erlangga, Jakarta.

Kotler, P., Keller, K.L. \& Sabran, B. (2009). Manajemen Pemasaran, Erlangga, Jakarta.

Lin, C.H., \& Kao, D.T. (2004). The Impacts of Country-of-Origin on Brand Equity. The Journal of American Academy of Business, Cambridge. 
Novalius, F. (2018, February 17). Indonesia is the 4th smartphone user in the world, this is the determination of the Minister of Industry to boost the telematics industry. Okezone. https://economy.okezone.com/read/2018/02/17/320/1860752/indonesia-pengguna-smartphone-ke4-dunia-begini-tekad-menperin-dongkrak-industri-telematika

Purwitasari, T., Yulianto, E., \& Wilopo (2018), Pengaruh Merek dan Negara Asal (Country of Origin) terhadap Keputusan Pembelian. Jurnal Administrasi Bisnis (JAB), Vol. 61 No. 1, 100-108.

Putra, A. S. U., Suharyono, Muwardi, M. K. (2016). Pengaruh Country Of Origin Dan Price Terhadap Keputusan Pembelian (Survei Terhadap Konsumen Xiaomi Di Indonesia, Malaysia, Singapura Dan Filipina). Jurnal Administrasi Bisnis (JAB), Vol. 40 No. 2, 192-200.

Riadi, E. (2016). Statistika Penelitian (Analisa Manual dan IBM SPSS), Andi, Jakarta.

Schiffman, \& Kanuk, L.G., (2010), Perilaku Komsumen, Edisi 2, PT Indeks Gramedia, Jakarta.

Silaen, S.G.R. (2018). Pengaruh Country Of Origin dan Brand Image Terhadap Minat Beli Konsumen (Studi pada Restoran Jepang Sushi Tei Sun Plaza Medan) - (Skripsi). http://repositori.usu.ac.id/handle/123456789/3534

Sugiyono, (2014), Metode Penelitian, Alfabeta, Bandung.

Sugiyono, (2016), Metode Penelitian Kuantitatif Kualitatif dan R\&D, Alfabeta, Bandung.

Tjiptono, F., (2016), Strategi Pemasaran edisi 3. CV. Andi Offset, Yogyakarta.

Wicaksono, B. R. (2016). Pengaruh Kualitas Produk Terhadap Keputusan Pembelian Layanan Internet yang dimediasi oleh Minat Beli, Fakultas Ekonomi Universitas Negri Yogyakarya, Yogyakarta, (Skripsi).

Widjoyo, I. O. (2013). Analisa Pengaruh Kualitas Layanan terhadap Kepuasan Konsumen pada Layanan Drive Thru McDonald's Basuki Rahmat di Surabaya. Program Manajemen Pemasaran, Universitas Kristen Petra. Jurnal Manajemen Pemasaran, Vol. 1 No. 1, 1-12.

Yasin, Nojaya, M., Noor, M.N., \& Oesman, M., (2007), Does Image of Country-of-Origin Matter To Brand Equity. Journal of Product \& Brand Managements. Vol. 16 No. 1, 38-48. 